\title{
Frequency characteristics of geomagnetic induction anomalies in Saurashtra region
}

\author{
P V Vijaya Kumar ${ }^{1}$, P B V Subba RaO ${ }^{1, *}$, C K RaO ${ }^{1}$, A K Singh ${ }^{1}$ and P Rama RaO ${ }^{2}$ \\ ${ }^{1}$ Indian Institute of Geomagnetism, Panvel, Navi Mumbai 410 218, India. \\ 2 Department of Geophysics, Andhra University, Visakhapatnam 530 003, India. \\ *Corresponding author.e-mail: srao@iigs.iigm.res.in
}

MS received 26 January 2016; revised 2 May 2017; accepted 10 May 2017; published online 7 October 2017

Magnetovariational studies were carried out along four different EW profiles in Saurashtra region in different phases, during January 2007-March 2012. Transient geomagnetic field variations (X, Y horizontal field and $\mathrm{Z}$ vertical field components) recorded along these profiles are analyzed to infer the electrical conductivity distribution of the region. The vertical field transfer functions which depict the characteristics of electrical conductivity distribution are presented in the form of induction arrows. From the spatial distribution of these arrows, it is inferred that the sediments filling the offshore basins have more conductivity than those basins in Saurashtra region. $Z / H$ pseudo sections along the four profiles in conjunction with tectonics and other geophysical methods permit to infer that the conductivity anomaly in the eastern part of the profiles is associated with the crustal/lithosphere thinning. The possible cause for these anomalies may be explained in terms of partial melts associated with mafic intrusions, related to Deccan and pre-Deccan volcanism. High resistive block related to underplating mantle material has been reflected in 1D models of long period magnetotelluric data and its thickness reduces from west to east. Lithosphere-asthenosphere boundary varies from 80 to $100 \mathrm{~km}$.

Keywords. Magnetovariational studies; Saurashtra; rifting; magmatic underplating; transient thermal effects; Reunion hotspot.

\section{Introduction}

Western continental margin of India (WCMI) has been affected by (a) Marion hotspot activity that led to the separation of Madagascar from India (Storey et al. 1995) and (b) Reunion hotspot activity that led to break up of the Seychelles Plateau from India (Besse and Courtillot 1988; White and McKenzie 1995). Huge amount of Deccan volcanic eruption took place during Reunion hotspot activity. During hotspot activity, interaction of plume with lithosphere leads to partial melts that is subjected to hydrothermal circulation which propagates through faults and fracture zones. This enhances the electrical conductivity of the medium and can provide independent constraints in tracing the plume-lithosphere interactions (Nolasco et al. 1998; Arora et al. 2003).

The electrical conductivity depth profile is obtained from electromagnetic methods. Electrical conductivity of crustal rocks varies over several orders of magnitude (0.1-100,000 $\Omega \mathrm{m})$, depends on petrological and physical parameters (conducting mineral phases (e.g., graphite, magnetite etc.), fluid contents (filled free water or released by dehydration mechanisms) and high heat flow 
(partial melting). Electrical conductivity profile is obtained either from magnetovariational (MV) or magnetotelluric (MT) methods. In the first method, we operate an array of magnetometers each of which records all the three components of the time varying earth's magnetic field and in the other method, we operate only one instrument but also make simultaneous recording of the two orthogonal components of the horizontal electric field (Telluric currents). The two methods are complimentary in the sense that MV has better lateral resolution and MT has a better vertical resolution. MV method is also known as geomagnetic deep sounding (GDS).

The present paper describes the frequency and polarization characteristics of the induction response observed in Saurashtra and surrounding region.

\section{Geology and tectonics}

Western India shield is dominated by three major Precambrian trends: (i) NNW-SSE Dharwar trend, (ii) NE-SW Aravalli trend and (iii) ENE-WSW Satpura trend. These three major tectonic trends were the zones of deformed and weakened crust along which later Phanerozoic rifting was facilitated (Biswas 1987; Bhattacharya and Yatheesh 2015). Kutch, Cambay and Narmada were formed along these trends during the Jurassic and were aborted in Late Cretaceous (Biswas 1987; Gombos et al. 1995). The NE-SW Aravalli trend continues across the Cambay basin into Saurashtra as a southwesterly plunging basement arch. Saurashtra horst within these intersecting rift zones has undergone upliftment and has experienced different phases of rifting, reactivation of ancient fault zones due to Deccan volcanism and is shown in figure 1(b).

Saurashtra arch trending in ENE-WSW basement features the plunges from shelf to deep waters and divides the Kutch-Saurashtra offshore into two sub-basins. It plays an important role in controlling the Indus fan sedimentation during the basin evolution (Bastia and Radhakrishna 2012). According to Sriram et al. (2006), the arch has evolved in three stages, viz., Late Cretaceous volcanic stage, Early Paleocene collapse and rifting stage, and lower to middle Miocene tilting stage.

Saurashtra rise separates the Surat depression from the Saurashtra basin. This depression is the extension of Narmada-Tapti rift zone towards west. The Surat depression consists of $8 \mathrm{~km}$ thick Tertiary, fine-grained, clastic sediments and is the source rock for the Bombay High (Biswas and Singh 1988; Banerjee et al. 1991).

Saurashtra peninsula is covered by Deccan traps (figure 1a), except along the coastal fringes where it is occupied by Tertiary and Quaternary sediments (limestone and alluvium). In the northern part, Mesozoic sedimentary rocks are exposed. Dixit et al. (2000) have improved the stratigraphy section of Saurashtra region by correlating the seismic velocities with the geological horizons obtained from well (Lodika and Dhandukha) data. The general stratigraphy of the peninsula, bounded between Precambrian basement at bottom and a spare cover of Tertiary and Quaternary sediments occur at the top, followed by Deccan traps and Mesozoic sediments (Merh 1995; Bhattacharya et al. 2004; Sheth et al. 2012). Deccan volcanic province in Saurashtra region consists of several intrusions of acidic, alkaline and mafic/ultramafic plugs (Merh 1995; Sheth et al. 2012). The significant volcanic plugs are Girnar, Osham, Barda, Alech in the western part and Vallabhipur, Palitana and Rajula in the south-eastern part of Saurashtra (Merh 1995). The western parts of volcanic plugs are predominantly acidic in composition with mafic/ultramafic intrusions (Chandra 1999), while plugs in eastern part are mainly composed of alkaline (Karanth and Sant 1995).

Basement map of Saurashtra and surrounding offshore region, shown in figure 1(c), is based on deep resistivity sounding (Singh et al. 2004) and seismic methods (Zutshi et al. 1989). The basement configuration by Zutshi et al. (1989) suggests westward slope with thick sediments in shelf break and deeper shelf regions. Saurashtra platform (SP) and arch region along with Kutch offshore basin (KOB) consist of moderate thick sediments $(6-8$ $\mathrm{km})$. Onshore region consists of NW-SE trending basin between Jamnagar and Mewasa with $3 \mathrm{~km}$ thick sediments is termed as Jamnagar basin (JB). Basin located between Una (UNA) and Bhagadana (BAG) consists of $8 \mathrm{~km}$ thick sediments and named as Ulva basin (UB). The thickness of the sediments in south and SW are less due to extensive volcanic activity in this region. It is interesting to note that the central part of the Saurashtra region forms a high land (Jasdan plateau, JP) consisting of thin sediments. Different station codes used are shown in figure $1(\mathrm{~d})$. 

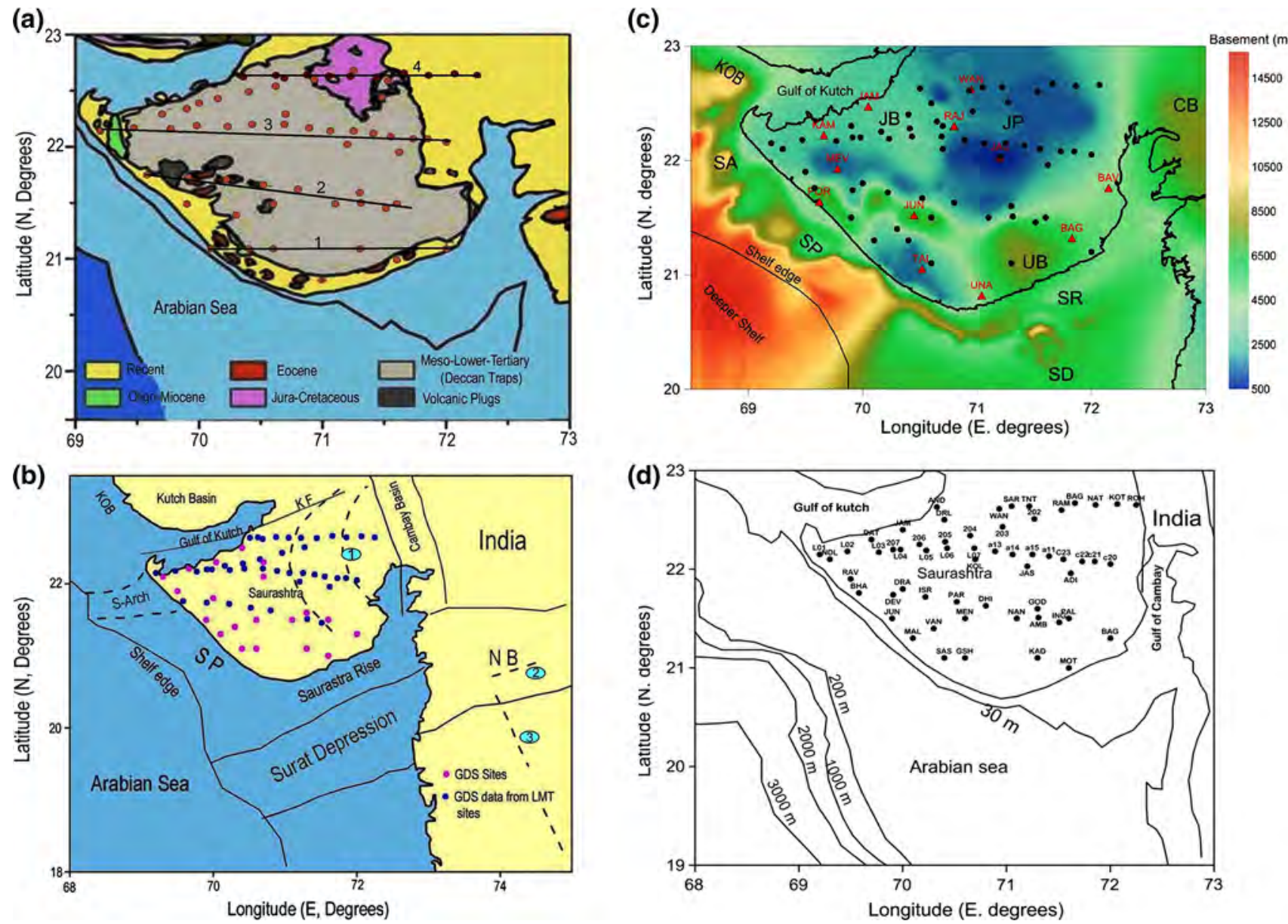

Figure 1. (a) Geological map of Saurashtra and the surrounding regions (after Merh 1995). Various fluxgate magnetometer and long period magnetotelluric stations installed in different phases are shown. (b) Site locations and various tectonic features of the western margin of India (after Biswas 2005). Offshore Saurashtra arch is shown as S-arch (after Bhattacharya and Subramanyam 1986). 1: Aravalli trend, 2: Satpura trend and 3: Dharwar trend. (c) Basement map of Saurashtra and the surrounding offshore region (after Zutshi et al. 1989; Singh et al. 2004) showing thick sediments in the shelf region. Thick sedimentary basins over Saurashtra region are also shown. KOB: Kutch offshore basin, SA: Saurashtra arch, JB: Jamnagar basin, JP: Jasdan plateau, CB: Cambay basin, SP: Saurashtra platform, UB: Ulva basin, SR: Saurashtra rise, SD: Surat depression and (d) various station codes used in the present work is shown.

\section{Different geophysical studies in Saurashtra region}

Geological and geophysical studies in Saurashtra region denote magmatic underplating (related to crustal melt intrusions), crustal thinning and lowvelocity zones (Kennett and Widiyantoro 1999; Mohan et al. 2012; Madhusudhan Rao et al. 2013, 2015). Different geophysical studies carried out in this region are gravity and magnetic (Mishra et al. 2001, 2004; Tewari et al. 2009), Deep Seismic Sounding (DSS) (Kaila et al. 1980; Rao and Tewari 2005), ISR seismic network (Chopra et al. 2014; Madhusudhan Rao et al. 2015), seismic tomography (Kennett and Widiyantoro 1999; Mohan et al. 2012; Praveen Kumar and Mohan 2014), magnetotelluric (Sarma et al. 2004) and magnetovariational (Subba Rao et al. 2012) studies. Gravity, seismic and magnetotelluric studies have brought out the presence of Mesozoic sediments below the Deccan traps (Satpal et al. 2006; Patro et al. 2015). Bouguer anomaly map of Saurashtra region suggested several highs and lows of varying amplitude (Mishra et al. 2004). Gravity lows are attributed to the sediments below the trap whereas the large wavelength gravity highs are associated with volcanic plugs of Deccan volcanism. Regional gravity studies carried out by Radhakrishana et al. (2002) and Tewari et al. (2009) bring out underplating mantle material related to the thermal influx by the Reunion plume activity (Madhusudhan Rao et al. 2015) beneath 
the Saurashtra region. Based on gravity and DSS studies, Rao and Tewari (2005), Tewari et al. (2009) and Praveen Kumar and Mohan (2014) suggest crustal thinning beneath the eastern part of Saurashtra region as the thickness of the crust varies from $38-32 \mathrm{~km}$ from west to east. Based on receiver function analysis, Chopra et al. (2014) suggest that northern part $(42-44 \mathrm{~km})$ of the crust is thicker than the southern part $(36-38 \mathrm{~km})$. Recent seismic tomography studies indicate low velocity upper mantle beneath Saurashtra and are interpreted to be imprints of volcanism (Kennett and Widiyantoro 1999; Mohan et al. 2012) that influences the crustal properties through magmatic underplating.

Regional conductance map of Saurashtra and surrounding area brings out high conducting anomaly over Surat depression containing carbonate-rich sediments (Subba Rao et al. 2012). This conductance map was derived from GDS stations occupied in south and south-central parts of the Saurashtra region. In the present study, we have obtained data from another 35 stations in the northern part of the Saurashtra region.

\section{Data source and processing}

Magson fluxgate magnetometers were used for data acquisition (with a sampling interval of $10 \mathrm{~s}$ ) in Saurashtra region in four different phases in southern and central parts of the region, while in central and northern parts of the region data was collected from 20 LMT sites as shown in figure 1(b). GDS data consists of time varying magnetic field components along three orthogonal directions, viz., geographic north $(\mathrm{X})$, east $(\mathrm{Y})$ and vertical downward $(\mathrm{Z})$ components. These magnetometers have been operated simultaneously at 35 sites in four different phases with interstation spacing of about 10-20 km. In addition, the magnetic field variations were also incorporated from 20 long period magnetotelluric (LMT) sites. These datasets were resampled for $1 \mathrm{~min}$ interval as few stations data is recorded for $30 \mathrm{sec}$ sampling interval.

Details about the GDS data processing are described by Subba Rao and Singh (2010). At a given site, observed time varying magnetic fields consist of normal and anomalous parts (Schmucker 1970). The normal magnetic field is defined as the vector sum of the contributions from the external source currents and part of the internal field that arises from induction in a layered structure.
The anomalous field arises due to induction in lateral electrical inhomogeneities. The transformation of the time varying magnetic fields into frequency dependent response functions will be helpful for deduction of the conductivity distribution through the transfer function formulation suggested by Schmucker (1970). Let, at any given frequency (or period), $X n, Y n$ and $Z n$ represent the normal fields. Then the observed magnetic field components at field sites $(X s, Y s$ and $Z \mathrm{~s}$ ) can be divided into normal and anomalous parts $(X s=X n+X a)$. In such a case, frequencydependent interstation transfer functions that relate the anomalous field components at a given site with the normal field components can be expressed as:

$$
\left[\begin{array}{c}
X a \\
Y a \\
Z a
\end{array}\right]=\left[\begin{array}{lll}
T x x & T x y & T x z \\
T y x & T y y & T y z \\
T z x & T z y & T z z
\end{array}\right] \times\left[\begin{array}{c}
X n \\
Y n \\
Z n
\end{array}\right]
$$

Under the assumption of uniform source field for short period fluctuations, when $Z n \rightarrow 0$ and $Z s \sim$ $Z a$, the vertical field transfer functions ( $T z x$ and $T z y)$ can be expressed by a linear combination of two horizontal components:

$$
Z s=Z a=T z x * X n+T z y * Y n .
$$

Similarly, the anomalous horizontal field transfer functions (Txx, Txy and Tyx, Tyy) are defined as:

$$
\left[\begin{array}{l}
X a \\
Y a
\end{array}\right]=\left[\begin{array}{ll}
T x x & T x y \\
T y x & T y y
\end{array}\right] \times\left[\begin{array}{l}
X n \\
Y n
\end{array}\right]
$$

In the present study, vertical field transfer functions have been estimated by selecting 10-12 events (only night time variations). The vertical field transfer functions were estimated for the period range of 8-128 min using robust regression technique (Egbert and Booker 1993). The magnitude $(S)$ and azimuth $(\phi)$ of these induction (real/quadrature) arrows are given by

$$
S=\sqrt{\left(T_{z x}^{2}+T_{z y}^{2}\right)}
$$

and

$$
\phi=\tan ^{-1}\left(\frac{T_{Z Y}}{T_{Z X}}\right) .
$$

The most convenient way to display and isolate the information contained in transfer functions 
(a)
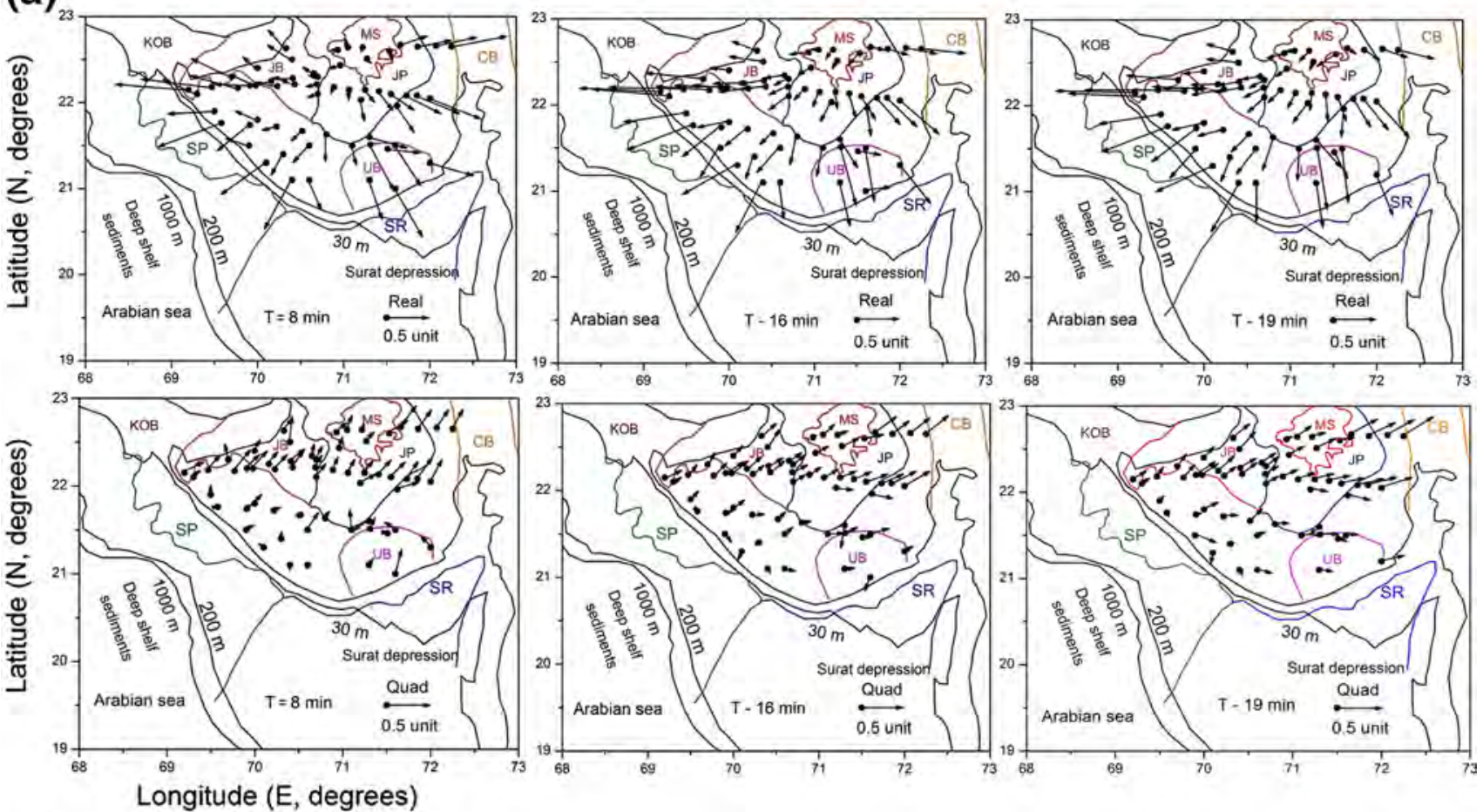

(b)
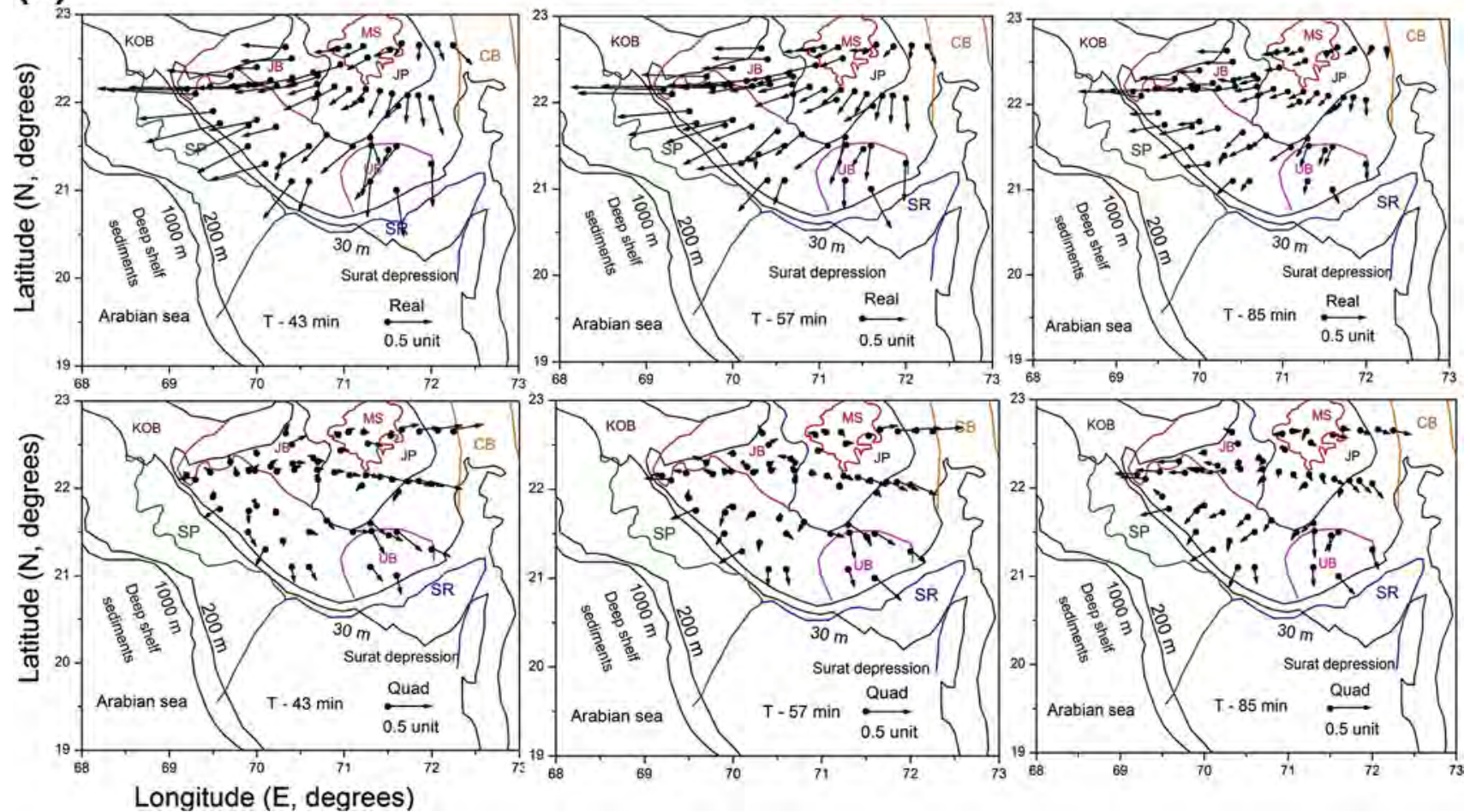

Figure 2. (a) Induction arrows (real and quadrature) corresponding to the periods 8, 16 and 19 are shown. Induction arrows at these periodicities are pointing towards thick sedimentary basins. (b) Induction arrows are shown for higher periodicities (43, 57 and $85 \mathrm{~min})$. It is interesting to note that as periodicity increases, for the southern part of the array the arrows are rotating in clockwise direction whereas for the northern part of the array the arrows rotate in anti-clockwise and point towards regional anomaly located in offshore region.

on the conductivity distribution (in the vicinity of the measuring sites) is through maps of real and imaginary induction arrows. The direction of the arrows is reversed so that they point towards regions of high electrical conductivity. When the induction arrows are plotted for all sites, they 
(a)

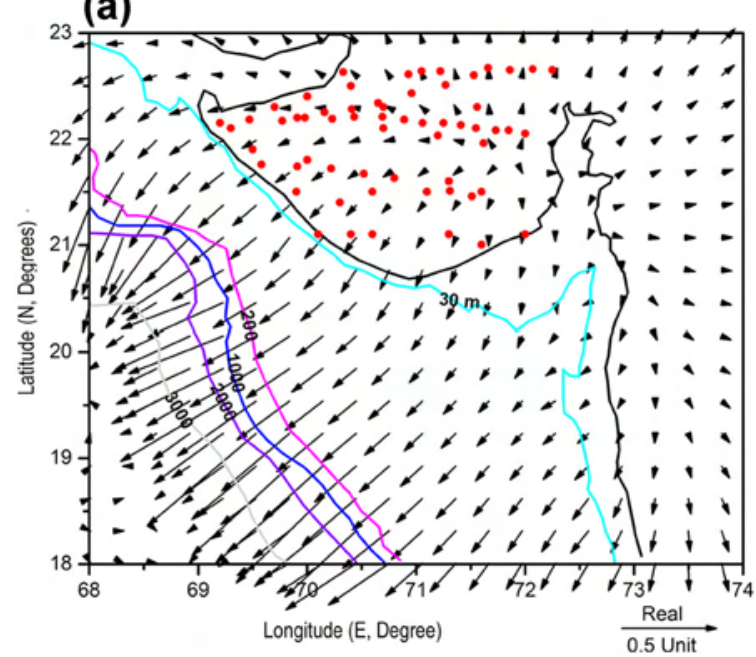

(b)

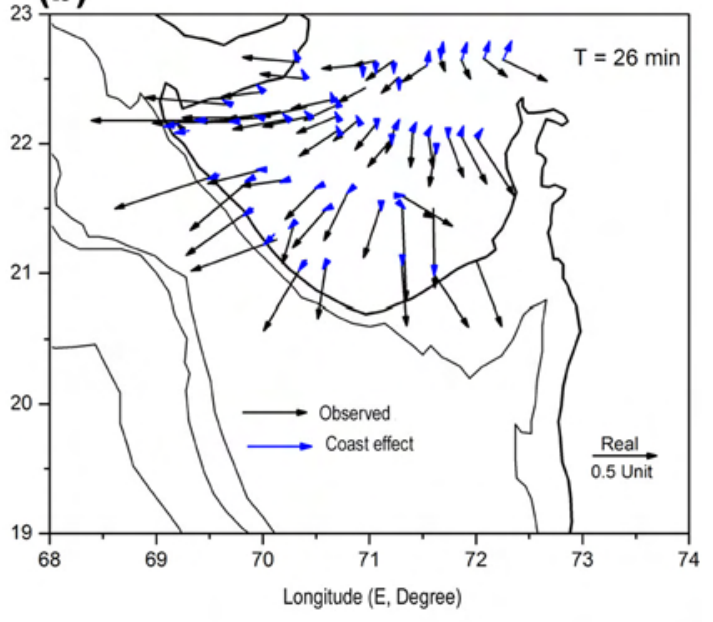

Figure 3. (a) Calculated real induction arrows at a period of $26 \mathrm{~min}$ by using $3 \mathrm{D}$ thin sheet approximation. They portray lateral variation in conductance due to land and sea water of variable depth. The arrows are shown for alternate grid points. (b) Comparison between observed and calculated real induction arrows. The observed coast effect is minimum due to the broader width of the continental shelf (after Subba Rao et al. 2012).

define the trend of the involved conductivity structures.

\subsection{Induction arrows}

Induction arrows (real and quadrature) corresponding to the periods $8,16,19,43,57$ and 85 min are shown in figure $2(\mathrm{a}$ and $\mathrm{b})$. In general, the observed induction pattern is partly controlled by bathymetry of sea water and local conductivity anomalies. For estimating the coast effect (i.e., due to resistivity contrast between land and sea water of variable depths), numerical computations have been carried out by Subba Rao et al. (2012) by using 3D thinsheet modeling (Vasseur and Weidelt 1977). Calculated coast effect is shown in figure 3(a) where calculated arrows are pointing towards deep sea and figure $3(\mathrm{~b})$ shows the estimated coast effect along with observed induction arrows for 26 min periodicity.

As observed from figure 2( $\mathrm{a}$ and $\mathrm{b}$ ), induction pattern in Saurashtra region can be divided into three parts: (a) At short periods real induction arrows in eastern part of Saurashtra region are pointing towards Cambay basin (shown as CB in figure) and as periodicity increases these arrows are rotating from ESE-SW direction and pointing towards Saurashtra rise (SR) and Surat depression. (b) Central part over Jasdan plateau where induction arrows are suppressed over Mesozoic sedimentary basin (MS) that are exposed in northern part of Saurashtra at shorter periods and as periodicity increases, arrows in northern part are rotating in NW direction and are pointing towards Jamnagar basin (JB) and Kutch offshore basin (KOB) whereas arrows in south and south central parts are pointing towards Ulva basin (UB) and Surat depression. (c) In northwestern part, the induction arrows with their NW orientation point at right angle to the Kutch offshore basin, in the western part they point towards WNW direction towards Saurashtra offshore basin/Saurashtra platform (SP) and whereas in southwestern part of array these arrows are pointing towards shelf edge sediments at 8-19 min periodicity. As periodicity increases, the trends of these induction arrows are changing from NW-WNW direction and are pointing towards SP and shelf edge sediments.

With increasing period, the behaviour of real induction arrows is changing. In western part of the array, the arrows are rotating from NW-WSW (in anticlock direction) and point towards thick shelf edge sediments, while induction arrows in southern part of array rotate in clockwise direction from SE-SSW and point towards Surat depression. These anomalous directional behaviours in induction arrows suggest a large-scale regional conductivity anomaly in the Saurashtra offshore region. The nearly uniform direction of the induction arrows at all sites at higher periods corresponds well with a regional pattern as observed earlier in the Kutch array and is related to a massive conductivity anomaly causing SSW-NNE directed flow of induced currents (Subba Rao et al. 2014).

The real induction arrows acquire peak values in the period range of $40-60 \mathrm{~min}$. In this period 
range, the quadrature arrows have nearly vanishing amplitudes and the direction of quadrature arrows reverse sign above and below this period. This critical period $\left(T_{c}\right)$ at which real arrows tend to be maxima and quadrature arrows flip their direction is characteristic of anomalous body. Using the relation given below, the critical period is used to estimate longitudinal conductance (product of conductivity ( $\sigma$ in $\mathrm{S} / \mathrm{m}$ and $\mathrm{Q}$ cross-sectional area in $\mathrm{m}^{2}$ ) of the anomalous body (Rokityansky 1982))

$$
G=\sigma * Q=5 * 10^{4}\left(T_{c}(s)\right)^{1.2}=9.8 * 10^{8} \mathrm{~S} . \mathrm{m}
$$

Using the relation given above, the estimated longitudinal conductance of the anomalous conductivity structure is about $9.8 * 10^{8} \mathrm{Sm}$.

\subsection{Hypothetical event analysis}

Projecting the induction arrows on to the line of the transect of GDS is carried out by the hypothetical event technique. In hypothetical event analysis (HEA), vertical field at all sites is computed with respect to external horizontal field of one unit with specified polarization (Bailey et al. 1974). Uniform horizontal field of one unit with an azimuth $\Theta$ in clockwise direction with respect to the north will induce currents such that vertical field can be written as:

$$
\begin{aligned}
Z_{r} & =\left(T_{z x}\right)_{r} \cos \Theta+\left(T_{z y}\right)_{r} \sin \Theta, \\
Z_{i} & =\left(T_{z x}\right)_{i} \cos \Theta+\left(T_{z y}\right)_{i} \sin \Theta .
\end{aligned}
$$

Magnitude and phase of anomalous field is given by

$$
\begin{aligned}
& Z_{m}=\sqrt{\left(Z_{r}^{2}+Z_{i}^{2}\right),} \\
& Z_{\emptyset}=\tan ^{-1}\left(\frac{Z_{i}}{Z_{r}}\right) .
\end{aligned}
$$

The advantage of HEA is that for different polarization of the hypothetical event, the induction response of the conducting body can be studied to get the information about the strike of the body.

Ingham et al. (1983) suggested a different presentation of transfer functions $Z_{r}$ and $Z_{m}$ in terms of $Z / H$ pseudosections. In order to know the variations of conductivity both with depth and along the profile (qualitatively), values of $Z_{m}$ or $Z_{r}$ from a number of sites along a traverse are contoured with distance along the horizontal axis and the vertical scale is the square root of the period.

\subsection{Pseudo-sections and polarization characteristics}

Using HEA, the induction response in vertical field was computed at all the stations on four different profiles for the selected period bands in the range of $8-128 \mathrm{~min}$. The response was calculated for the unit amplitude horizontal field polarized at varying angles from $-90^{\circ}$ to $+90^{\circ}$ degrees (with respect to north, in step of every $10^{\circ}$ ). Examination of $Z / H$ pseudo-sections along these profiles brings out strongest induction anomaly on the eastern part of the profiles (figures 4-7). As displayed in figures 4(a), 5(a), 6(a) and 7(a), the polarization angle for which the induction response is best seen is for $\mathrm{N} 28^{\circ} \mathrm{E}, \mathrm{N} 12^{\circ} \mathrm{E}, \mathrm{N} 13^{0} \mathrm{E}$ and $\mathrm{N} 22^{\circ} \mathrm{E}$ at south, south-central, north-central and north profiles, respectively.

The induction pattern does not vanish for polarization orthogonal to the one that produced best developed pattern, suggesting structure causing concentration of induced currents beneath the eastern part of Saurashtra region is largely $3 \mathrm{D} / 2 \mathrm{D}$ in character. Allowing for the diffusing nature of induction pattern with changing polarization, a

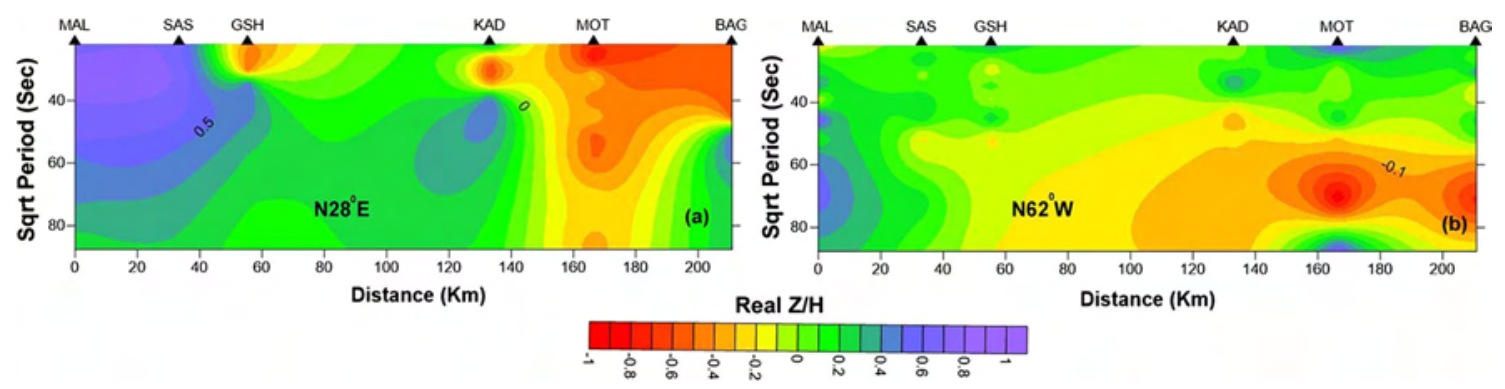

Figure 4. (a) Pseudosections of the anomalous vertical field $\mathrm{Zr}$ along the southern part of Saurashtra brings out anomalous conductivity zone in the eastern part of the region. (b) Presence of this anomaly in orthogonal part also denotes that it is $3 \mathrm{D}$ in nature. 

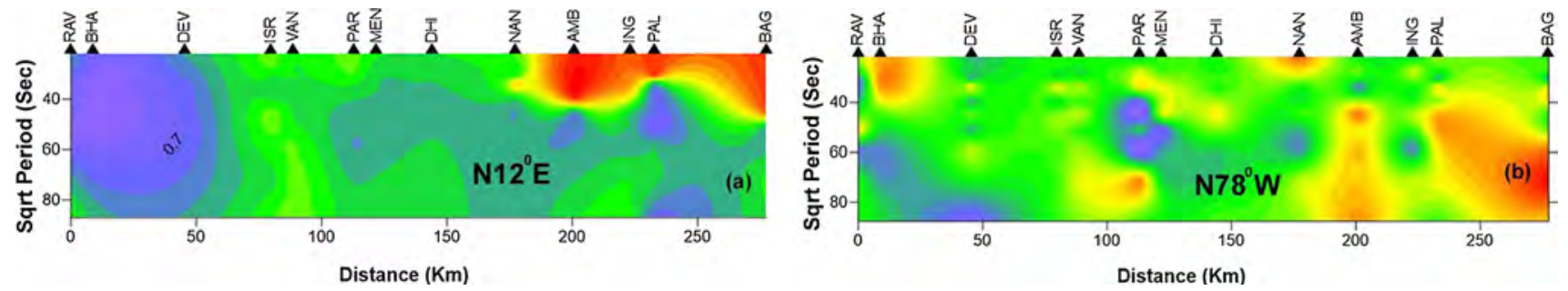

Figure 5. (a) Pseudosections of the anomalous vertical field $\mathrm{Zr}$ along the south-central profile brings out anomalous conductivity zone at shallow depth in the eastern part of the region. (b) This feature vanishes for orthogonal component.
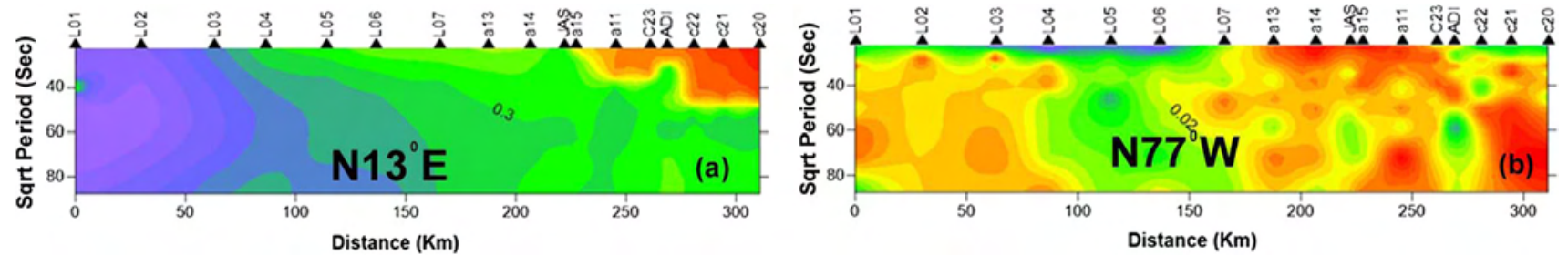

Figure 6. (a) Pseudosections of the anomalous vertical field Zr along the central part of Saurashtra region brings out anomalous conductivity zone in the eastern part of the region.
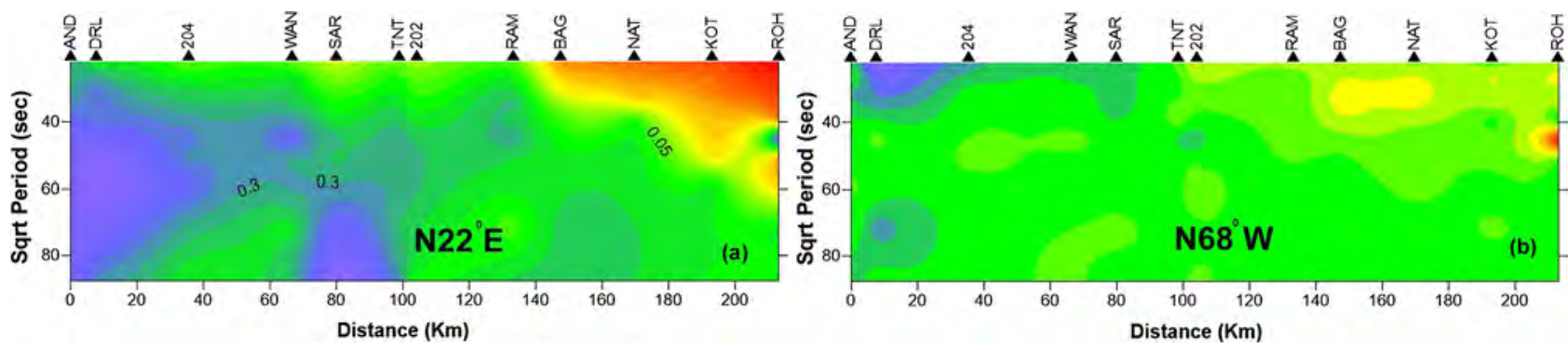

Figure 7. (a) Pseudosections of the anomalous vertical field Zr along northern part of Saurashtra region brings out anomalous conductivity zone in eastern part of the region that is shallow in nature. (b) This feature vanishes for orthogonal component of time period.

more critical examination of the pseudo-sections gives evidence of another well-defined conductivity anomaly in the eastern part of four profiles, the details of which are discussed below:

Profile-1: The induction pattern associated with conductivity anomaly beneath the eastern parts of all profiles is best brought in the pseudo-sections for polarization angle between $+10^{\circ}$ and $+30^{\circ}$. For example, the pseudo-section for southernmost profile corresponding to $+30^{\circ}$ shows high amplitude $Z / H$ values beneath stations MOT and BAG (figure $4 \mathrm{a}$ ) that extends westward towards KAD. The induction pattern does not diffuse for orthogonal polarization (figure 4b) and suggests that this conductivity anomaly is not completely $2 \mathrm{D}$ but has certain degree of $3 \mathrm{D}$ character. This $3 \mathrm{D}$ nature may be attributed to the thinning of the crust due to the deposition of Mesozoic sediments and/or was concomitant with the rise of Reunion plume prior to the extrusion of the Deccan volcanism (Tewari et al. 2009). This volcanism might have influenced the crustal properties through magmatic underplating and is observed as a low velocity upper mantle beneath Saurashtra region (Mohan et al. 2012).

Profile-2: Anomalous feature is observed for shallow periods (figure 5a) that gets diffused at higher periods. This suggests the shallow nature of the conductivity anomaly and diffuses completely from AMB-BAG for orthogonal polarization (figure $5 b$ ).

Profile-3: The induction pattern (figure 6a) characterized by high $Z / H$ is seen from low to high periods from JAS to C20, suggesting that the nature of the anomalous structure is extending into 
deeper layers. The presence of residual anomaly in the orthogonal component (figure 6b) suggests the $3 \mathrm{D}$ nature of the anomaly.

Profile-4: Anomalous conductivity anomaly is observed for shallow periods (figure 7a) that diffuses completely for orthogonal polarization (figure 7b). This profile cuts across the Mesozoic sediments located in NE part of Saurashtra region.

The MT study coincident with the central profile (in N-S direction) across Saurashtra region denotes high and thick sediments in the northern part of Saurashtra region (Patro et al. 2015). According to Sarma et al. (2004), northern part of the line joining Jodiya-Rajkot (in Saurashtra region) has thick Mesozoic sediments increasing from NE to NW, while southern part has less sediments. The present observations that anomalous induction effects are unambiguously seen along four profiles allow further inference that mapped zone, correlates with the track of the Reunion hotspot (Campbell and Griffiths 1990).

\section{Long period magnetotelluric (LMT) studies}

LMT data was acquired in northern part of Saurashtra region by using LEMI system. In this system, three components of the magnetic field variations $H x, H y$ and $H z$ (by using fluxgate sensor) and the electric field variations in the north-south $(E x)$ and east-west $(E y)$ directions are recorded by using non-polarizable $\mathrm{Ag} / \mathrm{AgCl}$ electrodes with a sampling interval of $1 \mathrm{~s}$. The LMT time-series is recorded for 4-6 weeks. LMT data is processed by using robust regression technique (Egbert 1997) by remote reference method. Unfortunately, we lost short period data due to noise (borehole motors used for groundwater pumping). We will be able to present results in the period range of $30-10,000 \mathrm{~s}$. In the present study, we present LMT results obtained along profile- 4 .

In a horizontally layered earth, currents and electric fields induced are at right angles to the inducing magnetic field. Thus, the electric and magnetic fields are interrelated by the relation

$$
\left[\begin{array}{l}
E x \\
E y
\end{array}\right]=Z\left[\begin{array}{l}
H x \\
H y
\end{array}\right]
$$

where $E x$ and $H y$ are the electric and magnetic fields measured along the NS and EW directions respectively. $Z$ is an impedance tensor defined as:

$$
Z=\left[\begin{array}{ll}
Z x x & Z x y \\
Z y x & Z y y
\end{array}\right]
$$

Apparent resistivity and phases are calculated from the impedance tensor $(Z)$ given by

$$
\rho_{i j}=\frac{1}{\omega \mu}|Z i j| * * 2
$$

and

$$
\emptyset_{i j}=\arctan (\operatorname{Im}(Z i j) / \operatorname{Re}(Z i j)),
$$

where $i=1,2$ and $j=1,2$.

Figure 8 (a and b) shows apparent resistivity and phase from 30 to $10,000 \mathrm{~s}$, and 1D resistivity depth section (using Occam's inversion, Constable et al. 1987) for the LMT sites occupied along profile-4 (that occupies northern part Saurashtra region). The one-dimensional model suggests that the high resistivity layer is at a depth of about $5-30 \mathrm{~km}$ and lithosphere asthenosphere boundary is at a depth of about 80-100 km. Over central part (Jasdan plateau), high resistive block has been uplifted and may be related to the underplating mantle material due to hotspot activity. Comparison of $1 \mathrm{D}$ models and $Z / H$ pseduosection along profile4 (figure 7) denotes that the thickness of the high resistivity block reduces as one moves from west to east.

\section{Summary}

Western continental margin of India has been affected by Marion and Reunion hotspots that led to several stages of rifting and crustal thinning (Mckenzie 1978; Biswas 1993), magmatic underplating (Cox 1980; Devey and Lightfoot 1986) and transient thermal effects. Outburst of Reunion plume lead to the enormous eruption of Deccan basalts in central and northwestern parts of the Indian subcontinent.

These Deccan basalts are generated by decompression melting of an abnormally hot mantle brought to the base of the lithosphere by a plume (White and McKenzie 1989). Based on tomography studies, the source for plume is located in the upper mantle (Kennett and Widiyantoro 1999; Mohan et al. 2012; Madhusudhan Rao et al. 2013, 2015) and center of the plume was close to the west coast of India. The track of this plume was traced up to the NS trending Cambay rift, to immediate east of Saurashtra peninsula (Campbell and Griffiths 1990). 

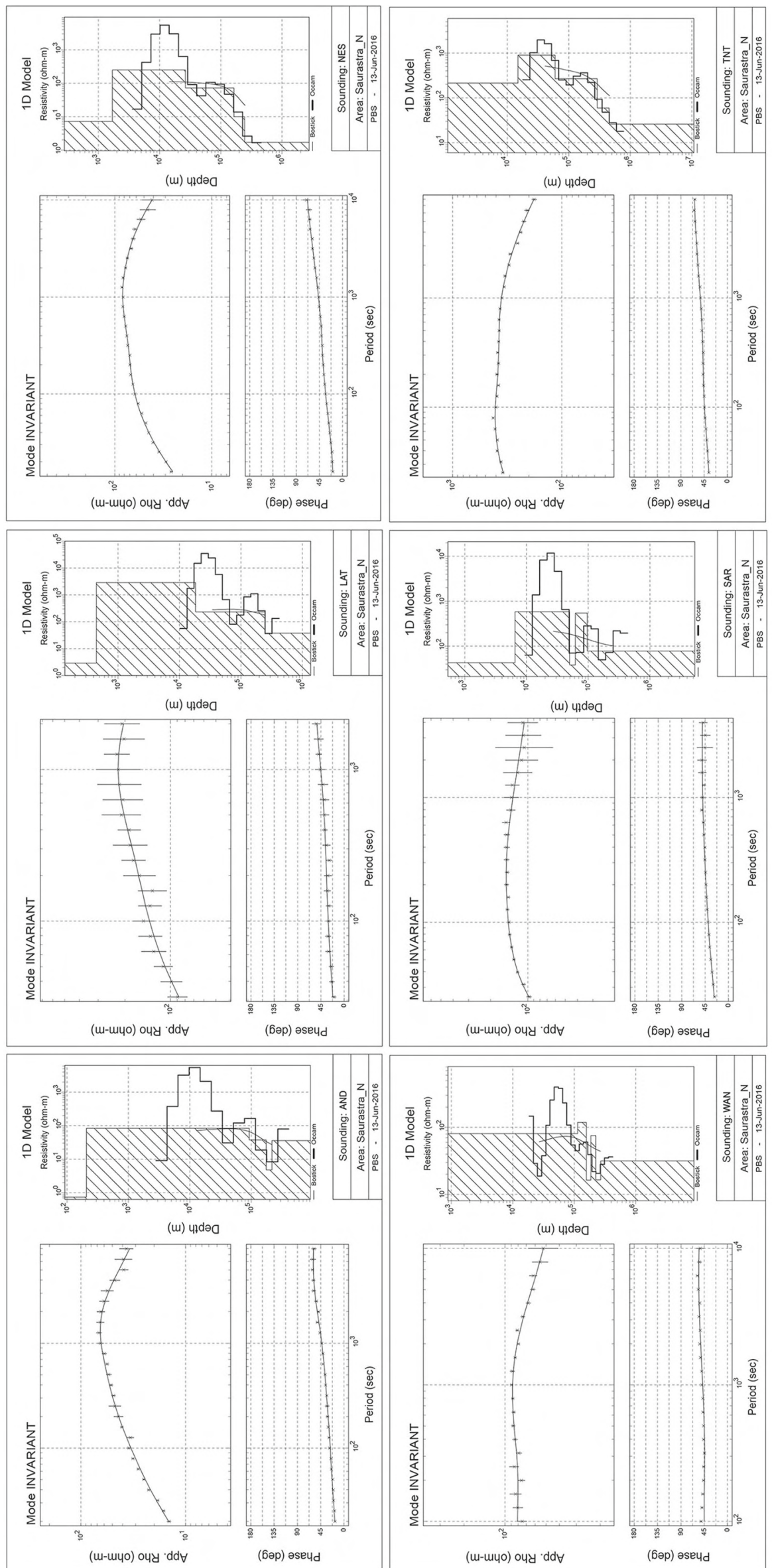

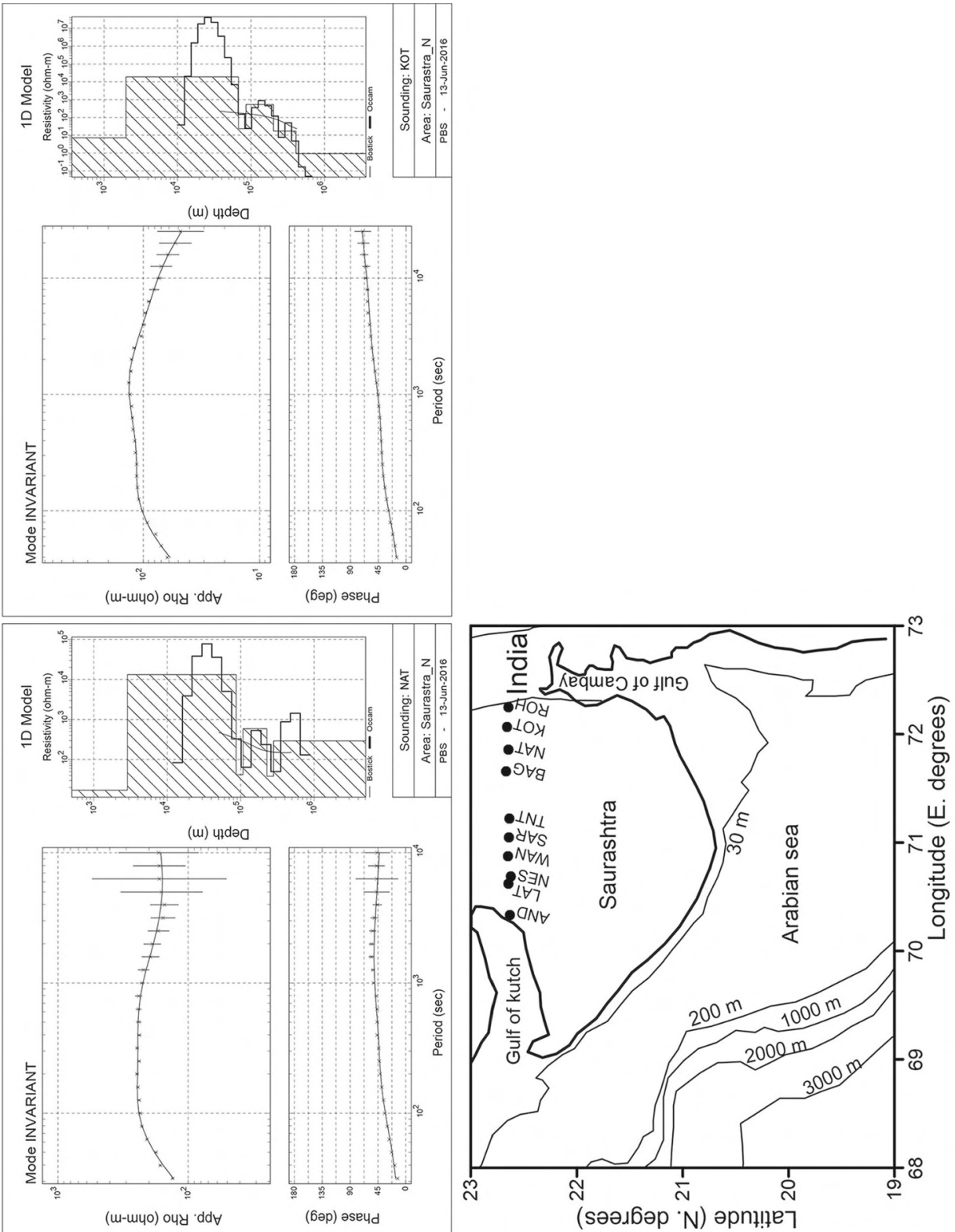

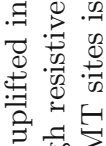

. 3

范苛

$x$.

․․․․․

0

密要

过 8

동 ᄚ

$\because \infty$

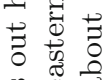

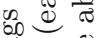

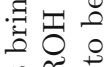

崖然

Pि

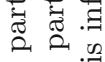

ॠై

륭

e

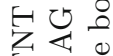

䏍芯

$\circ$ 표

像

ฮี

:

可

is

0 융

Z

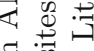

द्व

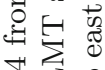

거용

듕 它苟

औे

的. :
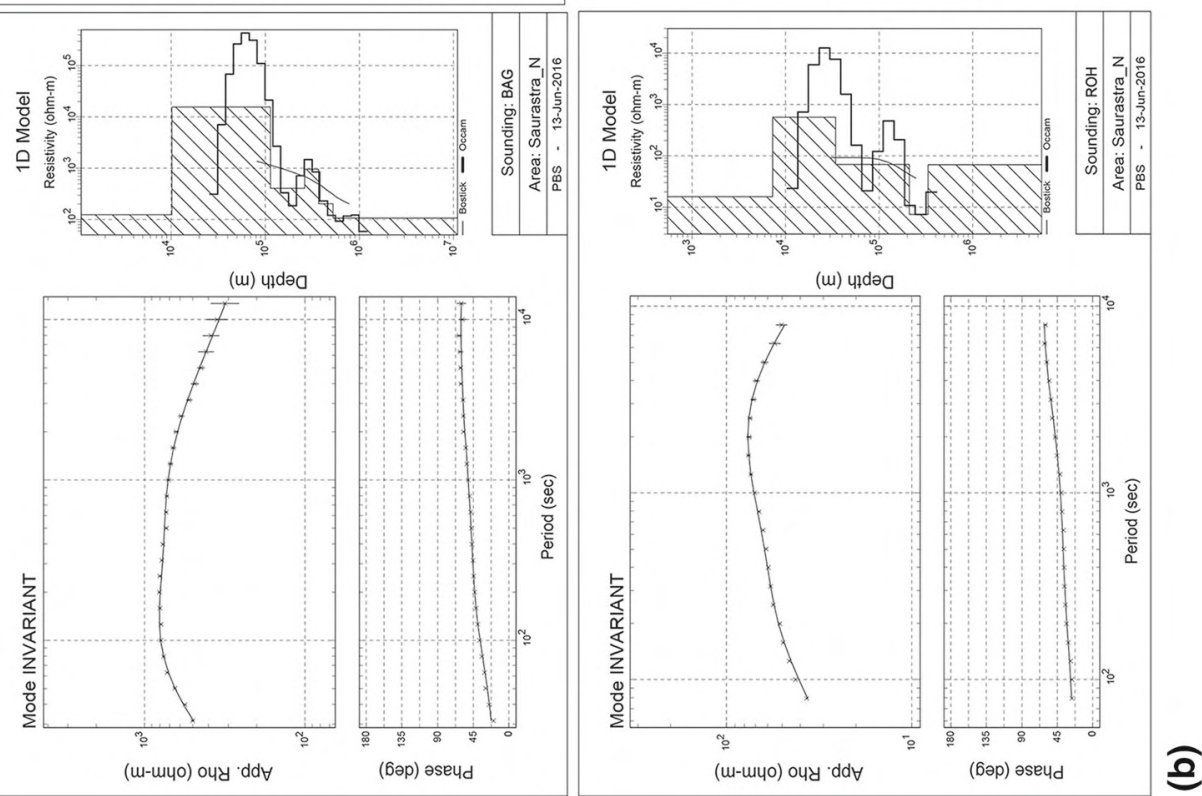

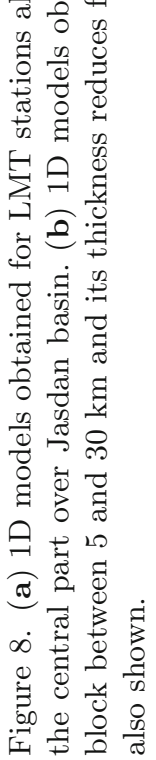


The zone of low seismic velocity (Kennett and Widiyantoro 1999; Mohan et al. 2012; Madhusudhan Rao et al. 2013, 2015) and underplating mantle material (reflected as a high resistivity block) beneath the Saurashtra region may represent partial melts of crustal and mantle material associated with the Reunion hotspot activity. The anomalous region observed in profile-1 represents SE part of Saurashtra that might have been affected by the hotspot activity. Based on broadband seismic work, crustal thickness reduces as one moves from west to east of Saurashtra region (Chopra et al. 2014). Thus, the anomalous zone along profile-1 may be attributed to thermal influx affected by the Reunion plume.

The observed conductivity anomalies in the eastern part of the profiles (2-4) suggest localized structure and could be attributed to the sediments plus mid-crustal conductivity anomaly related to fluids released by metamorphic reaction at the lower crustal level that is reflected as a low velocity zone in seismic studies carried out in Cambay basin (Kaila et al. 1990; Thiagarajan et al. 2001; Dixit et al. 2010).

At higher periods, uniform WNW orientation of induction arrows in central and western parts of Saurashtra region suggests the presence of massive conductivity anomaly causing SSW-NNE directed flow of induced currents. This regional anomaly may be attributed to the thick offshore sedimentary basin consisting of carbonate sediments (Biswas 1981). The presence of metamorphosed graphite schist in shale-dominated Mesozoic sequence or thin films of carbon resulting from the thermal influence of Deccan activity on Carbonate-rich formations can account for the high electrical conductivity anomalies seen in association with thick depo-centres of Mesozoic sediments. Since this region has been affected by various stages of rifting - crustal thinning, they are the possible mid-crustal conductivity anomalies. Most of the deep electromagnetic studies carried out in all the rifts bring out the conductivity anomaly at mid-crustal depths (Rokityansky 1982). This conductivity anomaly is treated as partial melting zone related to the uplifting of the hot mantle material as observed in seismic tomography studies.

\section{Acknowledgements}

The authors are grateful to Prof. D S Ramesh, Director, IIG, for his kind interest and constant support and permission to publish this paper. They thank the reviewers for their constructive comments and suggestions that improved the manuscript and the Associate Editor, Prof. N Purnachandra Rao for his encouragement. The authors also wish to thank Mr. N K Gadai and other colleagues of Rajkot Magnetic Observatory, Saurashtra University, for logistic support.

\section{References}

Arora B R, Subba Rao P B V and Vipul Nagar 2003 Electrical conductivity signatures of plume-lithosphere interactions in the Indian Ocean; Geol. Soc. India Memoir 53 393-418.

Bailey R C, Edwards G D, Garland G D, Kurtz R and Pitcher D 1974 Electrical conductivity studies over a tectonically active area in Eastern Canada; J. Geomag. Geoelectr. 26 125-146.

Banerjee V, Minal A K, Gupta A K, Balyan A K and Chaudhary D R 1991 On the origin of hydrocarbon reservoir in Bombay High: Stable isotopic studies of natural gases; $J$. Southeast Asian Earth Sci. 5(1-4) 339-343.

Bastia R and Radhakrishna M 2012 Basin evolution and petroleum prospectivity of the continental margins of India; Dev. Petrol. Sci., Elsevier Publication, 59 432p.

Besse J and Courtillot V 1988 Paleographic maps of the continents bordering the Indian Ocean since the early Jurassic; J. Geophys. Res. 93 11,791-11,808.

Bhattacharya S N, Karanth R V, Dattatrayam R S and Sohoni P S 2004 Earthquake sequence in and around Bhavnagar, Saurashtra, western India during AugustDecember 2000 and associated tectonic features; Curr. Sci. 86 1165-1170.

Bhattacharya G C and Yatheesh V 2015 Plate-tectonic evolution of the deep ocean basins adjoining the western continental margin of India - A proposed model for the early opening scenario; In: Petroleum Geosciences: Indian Contexts (ed.) Mukherjee S, Springer Geology, doi: 10. 1007/978-3-319-03119-4_1.

Bhattacharya G C and Subramanyam V 1986 Extension of the Narmada-Son lineament on the continental margin off Saurashtra, western India as obtained from magnetic measurements; Marine Geophys. Res. 8 329-344.

Biswas S K 1981 Basin framework, paleoenvironment and depositional history of the Mesozoic sediments of Kutch, western India; Quart. J. Geol. Min. Met. Soc. India $\mathbf{5 3}$ $56-85$.

Biswas S K 1993 Tectonic framework and evolution of graben basins of India; In: Rifted Basins and Aulacogens (eds) Casshyap S M et al., Gyanodaya Prakashan, Nainital 18 $18-32$.

Biswas S K and Singh N K 1988 Western continental margin of India and hydrocarbon potential of deep sea basins; 7th Offshore South Asia Conference, Singapore, pp. 170-181.

Biswas S K 1987 Regional tectonic framework, structure and evolution of the western marginal basins of India; Tectonophys. 135 307-327. 
Campbell Ian H and Griffiths Ross W 1990 Implications of mantle plume structure for the evolution of flood basalts; Earth Planet. Sci. Lett. 99 79-93.

Chandra R 1999 Geochemistry and petrogenesis of the layered sequence in Girnar Ijolite Series (GIS), India; In: The role of differentiation and allied factors in magmatism in diverse tectonic setting (eds) Srivastava $\mathrm{R} K$ and Hall $\mathrm{R}$ P, Oxford \& IBH Publishing Co., New Delhi, India, pp. 155-194.

Chopra S and Chang T M et al. 2014 Crustal structure of the Gujarat region, India: New constraints from the analysis of teleseismic receiver functions; J. Asian EarthSci. 96 $237-254$

Constable S, Parker R L and Constable C 1987 Occam's inversion: A practical algorithm for generating smooth models from EM sounding data; Geophysics 52 289-300.

Cox K G 1980 A model for flood basalt volcanism; J. Petrol. $21629-650$.

Devey C W and Lightfoot P C 1986 Volcanology and tectonic control of stratigraphy and structure in the western Deccan Traps; Bull. Volcanol. 48 195-207.

Dixit M M, Tewari H C and Visweswara Rao C 2010 Two-dimensional velocity model of the crust beneath the South Cambay Basin, India from refraction and wideangle reflection data; Geophys. J. Int. 181 635-652.

Dixit M M, Satyavani N, Sarkar D, Khare P and Reddy P R 2000 Velocity inversion in the Lodhika area, Saurashtra peninsula, western India; First Break 18 499-504.

Egbert G D 1997 Robust multiple-station magnetotelluric data processing; Geophys. J. Int. 130 475-496.

Egbert G D and Booker J R 1993 Imaging crustal structure in southwestern Washington with small magnetometer arrays; J. Geophys. Res. 98 15,967-15,985.

Gombos A M et al. 1995 The tectonic evolution of western India and its impacts on hydrocarbon occurrences: An overview; Sedim. Geol. 96 119-129.

Ingham M R, Bhingam D K and Gough D I 1983 Magnetovariational study of a geothermal anomaly; Geophys. J. Roy. Astron. Soc. 72 597-618.

Kaila K L, Tewari H C and Sarma P L N 1980 Crustal structure from deep seismic sounding studies along Navibandar-Amreli profile in Saurashtra, India; Geol. Soc. India Memoir 3 218-232.

Kaila K L, Tewari H C, Krishna V G, Dixit M M, Sarkar D and Reddy M S 1990 Deep seismic sounding studies in the north Cambay and Sanchor basin, India; Geophys. J. Int. 103 621-637.

Karanth R V and Sant D A 1995 Lineaments and dyke swarms of the lower Narmada valley and Saurashtra, western India; Geol. Soc. India Memoir 33 425-434.

Kennett B L N and Widiyantoro 1999 A low seismic wave speed anomaly beneath North Western India: A seismic structure of Deccan hotspot?; Earth Planet. Sci. Lett. 165 $145-155$.

Madhusudhan Rao K, Ravi Kumar M and Rastogi B K 2015 Crust beneath the northwestern Deccan Volcanic Province, India: Evidence for uplift and magmatic underplating; J. Geophys. Res. 120 3385-3405.

Madhusudhan Rao, M Ravi Kumar, Arun Singh and B K Rastogi 2013 Two distinct shear wave splitting directions in the northwestern Deccan Volcanic Province; J. Geophys. Res. 118 5487-5499.
Mckenzie D P 1978 Some remarks on development of sedimentary basins; Earth Planet. Sci. Lett. 40 25-32.

Merh S S 1995 Geology of Gujarat, Geological Society of India Publication, Bangalore.

Mishra D C, Bijendra Singh and Gupta S B et al. 2001 Major lineaments and gravity magnetic trends in Saurashtra, India; Curr. Sci. 80 1059-1067.

Mishra D C and Bijendra Singh et al. 2004 Gravity studies over Saurashtra Peninsula, India, some new insight; 5th Conference \& Exploration on Petroleum Geophysics, Hyderabad, India, pp. 75-78.

Mohan G, Ravi Kumar M, Saikia D, Praveen Kumar K A, Tiwari Pankaj Kumar and Surve G 2012 Imprints of volcanism in the upper mantle beneath NW Deccan volcanic province; Lithosphere 4 150-159.

Nolasco R, Tarits P, Filloux J H and Chave A D 1998 The effect of the Hawallian plume on the magnetic daily variation; J. Geophys. Res. 1998103 30,287-30,309.

Patro P K, Abdul Azeez K K, Veeraswamy K, Sarma S V S and Sen M K 2015 Sub-basalt sediment imaging - the efficacy of magnetotellurics; J. Appl. Geophys. $121106-$ 115.

Praveen Kumar K A and Mohan G 2014 Crustal velocity structure beneath Saurashtra, NW India, through waveform modeling: Implications for magnetic underplating; J. Asian Earth Sci. 79 173-181.

Radhakrishana M, Verma R K and Purushotham A K 2002 Lithospheric structure below the eastern Arabian Sea and adjoining west coast of India based on intergrated analysis of gravity and seismic data; Mar. Geophys. Res. $2325-42$.

Rao G S P and Tewari H C 2005 The seismic structure of the Saurashtra crust in NW India and its relationship to Reunion hotspot; Geophys. J. Int. 160 318-330.

Rokityansky I I 1982 Geomagnetic investigations of the Earth's crust and mantle, Springer Verlag, Berlin, Germany.

Sarma S V S, Patro B P K, Harinarayana T, Veeraswamy K, Sastry R S and Sarma M V C 2004 A magnetotelluric (MT) study across the Koyna seismic zone, western India: Evidence for block structure; Phys. Earth Planet. Int. 142 $23-36$.

Satpal O P, Sar D, Chatterjee S M and Sanjeev Sawai 2006 Integrated interpretation for sub-basalt imaging in Saurashtra basin, India; The Leading Edge 6 882-885.

Schmucker U 1970 Anomalies of geomagnetic variations in the southwestern United States; Bull. Scripps Inst. Oceanogr. 13 1-165.

Sheth H C, Choudhary A K, Cucciniello C, Bhattacharyya S, Laishram R and Gurav T 2012 Geology, petrochemistry, and genesis of the bimodal lavas of Osham Hill, Saurashtra, northwestern Deccan Traps; J. Asian Earth Sci. 43 176-192.

Singh S B et al. 2004 Delineation of basaltic covered sediments in the Saurashtra region using deep resistivity sounding studies; 5th Conf. Exposition on Petroleum Geophysics, Hyderabad, pp. 69-74.

Sriram K, Gupte S S, Kothari V, Bisen M and Waraich R S 2006 Structure and evolution of Saurashtra arch in Kutch-Saurashtra deep water area, western India; 6th Int. Conf. Exposition on Petroleum Geophysics, Kolkata, pp. $21-25$. 
Storey M, Mahoney J J, Saunders A D, Duncan R A, Kelley S P and Coffin M F 1995 Timing of hot spot related volcanism and the breakup of Madagascar from India; Science $267852-855$.

Subba Rao P B V, Arora B R and Singh A K 2014 Electrical conductance map for the Kachchh rift basin: Constraint on tectonic evolution and seismotetonic implications; Pure Appl. Geophys. 171 2353-2370.

Subba Rao P B V, Singh A K and Rao C K 2012 Regional conductance map of Saurashtra and surrounding region; Curr. Sci. 10325.

Subba Rao P B V and Singh A K 2010 Electrical imaging of the northern part of Lakshdweep Islands; Curr. Sci. 9812.

Tewari H C, G Surya Prakasa Rao and B Rajendra Prasad 2009 Uplifted crust in parts of western India; J. Geol. Soc. India 73 479-488.

Corresponding editor: N PURNACHANDRA RAO
Thiagarajan S, Ramana D V and Rai S N 2001 Seismically constrained two-dimensional crustal thermal structure of the Cambay basin; Earth Planet. Sci. 110 $1-8$.

Vasseur G and Weidelt P 1977 Bimodel electromagnetic induction in non-uniform thin sheets with an application to the northern Pyrenean induction anomaly; Geophys. J. Roy. Astron. Soc. 51 669-690.

White R S and McKenzie D 1995 Mantle plumes and flood basalts; J. Geophys. Res. 100 17,543-17,585.

White R S and McKenzie 1989 Magmatism at rift zones: The generation of volcanic continental margins and flood basalts; J. Geophys. Res. 94 7685-7729.

Zutshi P L, Jain M M and Srivastava H C 1989 Basement configuration of Kutch and Saurashtra basins; Oil Nat. Gas Comm. Bull. 26 53-62. 